\title{
Education and Enlightenment of Jewish Population in Slovakia until 1945. An Example of Microhistory of Prešov
}

\author{
By Eduard Lukác*
}

\begin{abstract}
The town Prešov can be proud of its rich cultural and educational traditions and they also represent the reason why Prešov is called "Athens upon Torysa". Educational needs of more races were satisfied in this multi-ethnical centre during its turbulent historical development and the level of these needs was conditioned by the social-political and economical conditions of this period. Since the end of the 18th century, the Jewish citizens were becoming an immanent part of the town's life and they were gradually founding their own educational, edifying and sport organizations alongside with the development of their religious community and so they were enhancing the cultural life of the town with their specific diversity. On the background of the main developmental tendencies, this paper summarizes the development of the individual Jewish school associations that provided education also for the pupils of other confessions; it points to the gradual participation of the cultural organizations and sport clubs in edifying activity and to their specific contribution in this area. The paper also includes the presentation of the most important Jewish people who contributed to the development of the town in the individual areas, to the spreading of educational level of the citizens, to the keeping of Jewish artifacts and to the presentation of Jewish culture through the first Jewish museum in Slovakia founded in Prešov, respectively they were very successful abroad. The paper also describes the impact of the tragic war events and deportation of the Jewish citizens, which caused its decimation and the decline of the educational and edifying efforts.
\end{abstract}

\section{Introduction}

The history of the Jewish community represents an essential part of social and cultural development of the most European cities. They are captured in form of the growing economic status of a city, in to-this-daypreserved material sights and buildings, in the contribution of influential people taking part in presentation of the city also from the point of view of development of education and edification, not only in the local scope. Research from the microhistory's point of view focuses on the analysis of narrowly defined phenomena (certain community, family and an individual), respectively everyday life and that is why these common events seen in more detail fulfill and help to understand the overall historic development ${ }^{1}$.

\footnotetext{
* Associate Professor, Institute of Pedagogy, Andragogy and Psychology, Faculty of Humanities and Natural Sciences of University of Prešov, Slovakia.

1. C. Ginzburg, "Microhistory: Two or Three Things That I Know about It," Critical Inquiry 1, (1993): 10-35.
} 
The first information about the existence of the Jewish community in Hungary, to which Slovakia belonged until the creation of The Czechoslovak Republic (1918 - 1938), come from Esztergom from 1050. The position of the Jews in Hungary during the Middle Ages was, compared to other European countries, on a much higher level. After the lost Battle of Mohács, a turbulent period came including the wars against Turkey, the reformation, violent re-catholization, anti-Habsburg revolts, et cetera, what also reflected in the unlucky fate of the Jewish citizens, in their allocation from towns and in the prohibition to do crafts and agricultural work. A gradual consolidation in the society came after the peace made in Satu Mare (1711) and it was evident in the development of the Jewish communities on the rural properties of rich landlords, what resulted in the development of their prosperity.

At first, Jews were coming to Prešov only to trade in the time when the provincial markets took place. Traders, craftsmen and the individual citizens, afraid from the competition of Jewish people, did not want them to enter the city permanently for a long time and the at-that-time royal orders also contributed to this. According to them, a Jew was not allowed to buy a flat or any other property in the town and under a threat of a high fine they were prohibited from being accommodated in the town. They had the aim to change this situation and asked the Provincial board in 1749 to be able to trade freely in Prešov, to build a synagogue and to found a cemetery. After the intervention of Provincial commission for Jewish issues, "Jewish traders were able to visit even weekly markets after paying a fee. But they were still under self-will of town offices and the army." ${ }^{2}$ The situation did not improve during the reign of Maria Theresa; it even led to curtailment of their possibilities while trading.

During the reign of Joseph II, the position of Jews in the society was changed with the order of "Systematica Gentis Judaicae Regulatio" (Systematic Regulation of the Jewish Nation, 1783), which enabled the Jews to move freely except to mining towns; the restrictions in trade were removed, their children were allowed to study at Jewish schools directed by the state as well as at Christian schools and universities. In 1790, after the death of Joseph II., the law "De Judaeis" was issued and confirmed the previous advantages. "Jews, living in Hungary and in surrounding areas, will stay in all free royal towns and in other settlements (beside royal mining towns) in the position that they were in on the $1^{\text {st }}$ of January $1790 "{ }^{3}$. This law was a huge success and enabled other development of the Jews in Hungary. Post-revolutionary changes led to other adjustments that culminated in recognition of the fully-fledged position of the Jews by the emancipation act accepted by the Hungarian parliament on the $25^{\text {th }}$ of November 1867, which (beside others) in its first paragraph says: "Israeli

2. P. Kónya and P. Landa, Stručné dejiny prešovských Židov [A brief history of Jews in Prešov] (Prešov: Podnik výpočtovej techniky a. s. Bratislava divízia Prešov pre Židovskú náboženskú obec Prešov, 1995), 11.

3. G. Amir, Prešov - osud židovskej obce, jednej z mnohých [Prešov - the fate of Jewish community, one of the many] (Bratislava: SNM - Múzeum židovskej kultúry, 2004), 26. 
inhabitants of the country are declared authorized to use all civil and political rights as Christians" and in the second paragraph "Every law, habit or order contradicting this is no more valid." ${ }^{4}$ Prejudices built for centuries and anti-Semitic ideas, fixed and still intentionally promoted also by political powers stayed long in the mind of other citizens and, unfortunately, they are not an exception also in the contemporary society.

\section{First Jews in Prešov and the Beginnings of the Educational Effort}

The first Jewish citizen of Prešov was Marek Holländer (1760 - before 1848). "An exact year of his arrival to Prešov is not known, but it was probably between 1784 and 1789". ${ }^{5}$ An initial disfavor of citizens and the town-council changed, after the proof of Holländer's trading capability and financial benefit, into trust shown by providing an exclusive right for him to sell spirits and wine in town. Despite the long-lasting aversion of the local trade guild, a mutual conciliation happened so Marek Holländer ordered the construction of a Neptune statue over one of the town tanks, which was later re-built into to-this-day existing fountain. ${ }^{6}$ In this period, there was not any Jewish community in the town so Holländer took part in clerical life of the Jewish community in Šariššké Lúky, whom he was helping also financially. "Holländer did not restrict his activity to only financial area and politics, but he also cared for the clerical needs of the Jewish public. He wanted to get theological and secular literature to the Jewish communities, to village Yeshivas and Talmud schools."7 Also other families like Schifs, Schefers, Barkans, Janowitzs, Jubilers, Spiegels, Rosenbergs et cetera started to move to Prešov, which was an important trading and cultural center of the given region, and their arrival required gradual enactments of the Jewish community, corresponding institutions, own cemetery and "a religious school Beth Midrash started to teach in one of the houses, no more secretly but officially." 8 The Jewish religious community started to be officially active in 1830 and its first representative was Leo Holländer, the son of the first Jew that settled in Prešov. "In the period of circa sixty years, from the settlement of the first Jew in the free royal town Prešov until the revolution of $1848 / 49$, the foundations of the new advanced modern Jewish community were laid with formation of the main institutions. Despite a small number of their members, it quickly became one of the leading communities in the broader surrounding and successfully took the role of the Jewish center of

4. T. Austerlitz, and P. Kónya, Kodeš z Orkucan. Súdny proces na základe falošného obvinenia z rituálnej vraždy v r. 1764 [Kodesh from Orkucany. The trial on false charges from ritual murder in 1764] (Prešov: Podnik výpočtovej techniky, 1993$), 17$.

5. P. Konya, "Leo Holländer, prvý žid v Prešove"["Leo Holländer, the first Jew in Prešov"], in Marek Holländer a vznik židovskej náboženskej obce v Prě̌ove, ed. D. Landa and P. Konya (Prešov: Súkromná tlačiareň Juraj Kušnír, 1999 ), 22.

6. B. Klein-Tesnoskalský, Pamätná kniha mesta Prešova. Diel II. (1701 - 1919) [Memory book of Prešov. Part II] (Prešov: Štátna vedecká knižnica, 2012), 83.

7. G. Amir, 2004, 30.

8. Ibid., 32 
the whole Šariš area." 9 The first private Jewish folk school, which was founded in 1843 and had three teachers, certainly also contributed to this change. After a few years, the requirements for education level of the Jews in the town increased so a new school was built at street Konštantínova. Beside the school, the first Jewish synagogue was also built.

The person, who significantly contributed to the spreading of education and edification, was Dr. Solomon Marcus Schiller - Szinessy (1820 - 1890), the first rabbi of the Jewish community of Prešov, who was active there since 1844. From 1847 to the revolutionary events he was active as an associate professor at the theological academy of the famous Evangelic College in Prešov. ${ }^{10} \mathrm{He}$ was teaching Hebrew and the Old Testament; he was responsible for the religious lessons for the Jewish students and was also teaching at the Jewish religious school Talmud Torah. His sermons in German language were so popular that also many citizens of Prešov with other confessions visited them on Saturdays. His participation in the revolutionary events radically affected his further life, which was from 1878 until his death connected to his activity in the function of professor at The University of Cambridge.

In the context of contents of this paper it is necessary to say that the young members of the Jewish community gained higher education also at the local Evangelic College, whose first Jewish student was Leo Holländer.

In the school year $1840 / 1841$ it was attended by 1 Jewish pupil, in $1847 / 1848$ there were 9 of them, but in 1892/1893 their number increased to 144, what represented $31.5 \%$ of the total number of pupils. The highest number of the Jews studied at Evangelic College Secondary Grammar School; in the school year 1877/1878 51 Jews studied at the whole School ${ }^{11}$, the Jewish students of the first year of this School made 48.2\% during 1896 -1909 and during $1887-1911$ Jewish pupils of the $8^{\text {th }}$ year of the School made $38.1 \%$.

9. P. Kónya, 1999, 21.

10. Evangelic College in Prešov, founded in the year 1667, belonged to the most important protestant schools of the Upper Hungary and during its activity 4 school institutions became a part of it: secondary grammar school, theological academy, law academy and men training school.

11. D. Vasil’ová and L. Franková, Z dejín prešovského kolegiálneho gymnázia (1804 - 1918) [From the history of Evangelic College Secondary Grammar School (1804 1918)] (Prešov: Filozofická fakulta Prešovskej univerzity, 2012), 144. 
Table 1. The Structure of the $8^{\text {th }}$ Year Students of Evangelic College Secondary Grammar School in Presov during $1887-1911^{12}$

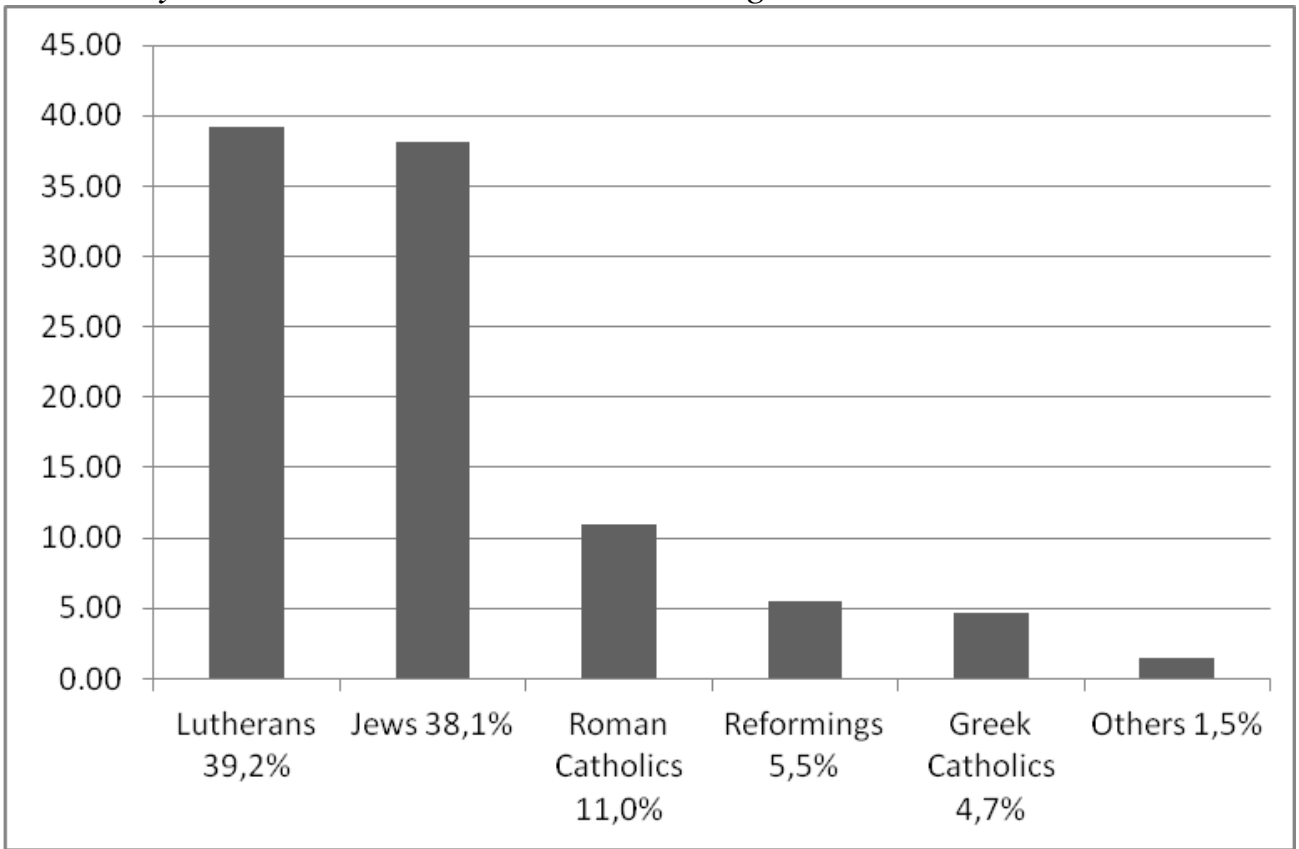

Under the influence of the increasing number of the Jewish citizens, the first Jewish school was in 1857, when it was visited by 75 pupils, turned into the state Jewish folk school with four study years with German as a teaching language and in the same year the new building was built for it. ${ }^{13}$ The school, which gained official approval from the government board and bishop from Košice, belonged after the division to the orthodox Jewish community.

During 1852 - 1872, Chaim David Lippe (1823 - 1900) was the cantor and teacher of the religious education in Prešov. He had worked since 1873 in the Jewish printing office in Vienna, which was issuing various popular papers, as well as his bibliographic lexicon "Bibliographisches Lexicon der Gesammten Jüdischen Literatur der Gegenwart und Adress-Anzeiger"

The result of the session of the whole-Hungarian Jewish congress, which was from $10^{\text {th }}$ November 1868 to $23^{\text {rd }}$ February 1869 , was the division to two directions: to orthodox and neologic. ${ }^{14}$ After the creation of the reform group of the Jewish confession, the so-called neologic community in 1871 (after parting of orthodox community), the second Jewish elementary school was founded in Prešov - neologic folk school,

12. A. Kónyová, "Židia na Prešovskom evanjelickom kolégiu do roku 1918" ["Jews at Evangelic College of Prešov until 1918"] in Židia pred a za Karpatmi v priebehu stáročí, ed. P. Kónya (Prešov: Vydavatel’stvo Prešovskej univerzity v Prešove, 2013), 242.

13. R. J. Buchler, (Ed.) Encyklopédia židovských náboženských obcí na Slovensku. L$R$ [Encyclopedia of Jewish religious communities in Slovakia. L-R] (Bratislava: SNM Múzeum židovskej kultúry, 2010), 162.

14. P. Meštan, "Stručný pohl'ad do histórie" ["A brief view into history"] in Židia pred a za Karpatmi v priebehu stáročí, ed. P. Kónya (Prešov: Vydavatel'stvo Prešovskej univerzity v Prešove, 2013), 14. 
which was, since 1886, using the new modern school building near the neologic synagogue at the contemporary street Konštantínova. The first synagogue was built at Konštantínova street during 1847-1849, but after the great fire in town in 1887, a neologic synagogue was built in its place. Leo Holländer was mainly the one who helped because he had a high status in the whole town. Neologic folk school after the moving to the new place "represented the most modernly equipped school in the town." ${ }^{15}$ Its four teachers were responsible for teaching of circa 150 children before the First World War. The building was used as a school until the creation of war Slovak Republic, the period of tragic events also for the Jews in Prešov.

The neologic Jewish community was also represented by its long-time rabbi Dr. Mayer Austerlitz, active during 1860 - 1913. He contributed to the new growth of the clerical life of the community, applied daily public worships, "regular teaching of religion in the school and founded very famous school Talmud - Torah." 16

After the parting of the orthodox Jewish community in 1871, a complex of buildings serving its life and religious ceremonies was gradually formed. This district consisted of the gradually built institutions: orthodox synagogue (built in 1898) - today the only active synagogue in the town, in which there is a Jewish museum on the first floor, old orthodox chapel, the building of the rabbinate, the administrative building and Sephardic synagogue. In 1873, a kindergarten and a five-class orthodox folk school were founded. ${ }^{17}$ There were five teachers teaching religious education before the First World War and another five teachers teaching secular subjects in this orthodox folk school. The school was attended by more than 200 pupils at that time. The orthodox branch of the Jews also had its own kindergarten in the town, which was attended by circa 100 children.

The rabbi school Yeshiva provided higher education for the preparation of the Jewish priests - rabbis, who belonged to the orthodox Jewish community and it was situated in the building of the above mentioned orthodox folk school. "The first orthodox rabbi of the independent rabbinate was during 1893 and 1895 Móric Arje Roth. He opened Yeshiva in Prešov and became one of the founders of the religious Zionist movement in Hungary." ${ }^{18}$ Noah Baruch Fischer became the rabbi of the orthodox community in 1905 and during his activity Yeshiva had more than 80 pupils from the whole monarchy.

Rabbi school (Yeshiva) flourished in the period of the existence of The Czechoslovak Republic mainly under the leadership of the rabbi Moshe Chaim Lau, who was active in Prešov during 1928 - 1935. "He presented his sermons and speeches with great excitement. As a talented rhetorician he persuaded his listeners about the need for love to co-religionists and to the country of Israel. He published articles about the Jewish family and about

15. P. Švorc, (Ed.), Sprievodca po historickom Prešove [A guide through the historical Prešov] (Prešov: UNIVERSUM, 2006), 147.

16. P. Kónya and P. Landa, 1995, 42.

17. R. J. Buchler, 2010, 162.

18. Ibid., 163. 
problems, which were current at that time, like for example education of girls in schools Bais Yaakov, labor organization of religious workers et cetera, in the Polish, Hebrew and Yiddish language." ${ }^{19}$ During the time when he was leading the rabbi school he invited also other rabbi lecturers to cooperate and the school "had about 150 students from Slovakia, Poland, Hungary, Romania and Austria." 20 There was also a library next to the school, which was founded in 1929 with the foundation of the rabbi school from the donations of the individuals. By the end of 1932 the library owned 100 bands, which were available to the academic public and the librarian was Nisan Amarand.

He dedicated some time to every student and tried to develop also their necessary rhetorical abilities. Students of Prešov did not forget their rabbi even after he had left to be a rabbi in Pjotrków in Poland. In summer 1942 they prepared an escape route for him to Slovakia, but every time they started to talk to him about this possibility he declined it vigorously, because he did not want to leave the members of his community. Consequently, he was transported to the concentration camp in Treblinka, where he died in 1943. "His pupils in Yeshiva were thankful listeners, because he was unveiling the secrets of the biblical commandments and all horizontal and vertical knowledge of the literature, law, medicine, geometry, geography, astronomy and even parables and aphorisms. He was the sympathizer of the tolerance, dialogue and exchange of views. His unveiling of teaching and advice equaled the secular study." 21

The continual schools were the educational institutions, which prepared pupils after the finish of a primary school to the trade activities. Jewish private apprentice continual school for locksmiths was a three-class educational institution with Slovak as a teaching language. It was directed and financed by the Jewish industrial and shop organization for tools and locksmithery in Prešov, whose abbreviation was "JOINT". The president of the executive board was Dr. Karol Ferbstein. The organization required the ministry to be able to found the school on the $11^{\text {th }}$ August 1923 and the Ministry of Education and National Edification in Prague confirmed its foundation by its act number $48119 / 24$ - III from the $4^{\text {th }}$ March $1925 .^{22}$

The school was situated at Žl'abová street number 6 and the president of the executive board of the organization, Dr. Karol Ferbstein, was at its head. ${ }^{23}$ The teaching was free for the pupils and was realized on Sundays,

19. G. Amir, 2004, 49.

20. R. J. Buchler, 2010, 164.

21. D. Landa, Storočnica. Život a práca židov v Šariši v posledných troch storočiach [Centenary. Life and work of the Jews in Šariš in the last three centuries] (Prešov: Židovská náboženská obec v Prešove, 1997), 55 - 56.

22. State archive in Prešov, The Fund District Authority in Prešov 1923 - 1944, inventory number 224 , box number 60 , Jewish private apprentice continual school, Act of Ministry of Education and National Edification in Prague from 4.3.1925.

23. E. Lukáč, Stredné školy v Prešove do roku 1945 [Secondary schools in Prešov until 1945] (Prešov: Privatpress, 2002), 130. 
Tuesdays, Wednesdays, Thursdays and Saturdays. The pupils were accepted to study between the $1^{\text {st }}$ and the $15^{\text {th }}$ September of the given school year: ${ }^{24}$

Table 2. Teaching in Jewish Private Apprentice Continual School for Locksmiths ${ }^{25}$

\begin{tabular}{|c|c|c|c|c|c|}
\hline \multirow{3}{*}{ Study Subjects } & \multicolumn{5}{|c|}{ Number of lessons per week } \\
\hline & \multicolumn{3}{|c|}{ In special classroom } & \multirow{2}{*}{ Total } & \multirow{2}{*}{$\%$} \\
\hline & $I$. & II. & III. & & \\
\hline $\begin{array}{l}\text { Trade-business writings, } \\
\text { arithmetic, calculation, accounting }\end{array}$ & 3 & 2 & 1 & 6 & 20 \\
\hline Civic theory & - & - & 1 & 1 & 3.33 \\
\hline Special drawing & 2 & 3 & 3 & 8 & 26.67 \\
\hline Special theory & 2 & 2 & 2 & 6 & 20 \\
\hline Teaching in workshops & 3 & 3 & 3 & 9 & 30 \\
\hline Together & 10 & 10 & 10 & 30 & 100 \\
\hline
\end{tabular}

The department of the Ministry of Education and National Edification in Bratislava objected to its activity already in 1930 and it stated in its act from the $14^{\text {th }}$ February 1930 number 52421/I-1929 that according to to-thattime valid regulations, Talmud Torah "is not public nor private school". ${ }^{26}$ In school year 1929/1930, this "school" (organization) was attended by 33 pupils, who were not attending any other school approved by the state so they did not finish the compulsory school attendance stated by the law. That is why the school inspector of Prešov M. R. Hrnčiar in the letter number 3460/929 from the $16^{\text {th }}$ December 1929 wanted them to be moved to the public school, what he also urged on the $5^{\text {th }}$ February 1930 and consequently on the $25^{\text {th }}$ February 1930. At the same time, the parents of the mentioned children were invited to enroll them to a regular school within three days, what should have been evidenced by the confirmation of the school's board.

Because the organization JOINT, which financially helped the Jewish apprentice school, did not have much money, the school had to be closed on the $1^{\text {st }}$ April 1933. A record from the general meeting of the Jewish industrial and shop organization of Prešov, which took place on the $7^{\text {th }}$ November 1933, provides evidence for that, because a bad financial situation was discussed there. ${ }^{27}$ The organization JOINT terminated in 1935. In 1912, there was another splitting in the Jewish community, when 26 Chasid families, who created their own organs and institutions, left the orthodox community. Beside the chapel, the Klaus synagogue built in 1935, also Beth Midrash (House of Learning) was founded, which had three

24. State archive in Prešov, The Fund District Authority in Prešov 1923 - 1944 , inventory number 224 , box number 60 , Jewish private apprentice continual school, Curriculum of special continual school for apprentices of locksmithery near workshop of Jewish industrial and shop organization of Prešov.

25. Ibid.

26. State archive in Prešov, The Fund District Authority in Prešov 1923 - 1945, inventory number 126, box number 9 , prohibition of school Talmud Torah.

27. State archive in Prešov, The Fund District Authority in Prešov 1923 - 1944, inventory number 224 , box number 60 , Jewish private apprentice continual school, Report from general meeting of JOINT organization. 
classrooms. "The teachers were Chasid rabbi Šimon Fuchs and Majer Rosenwasser." 28

The administrator of the orthodox Jewish folk school was for a long time Jozef Habermann, who retired on the $1^{\text {st }}$ March 1930. This school was provided with the clothes for fourteen children in 1929 by the Czechoslovak Red Cross and Board organization as a Christmas contribution. ${ }^{29}$ In the following year, the teacher Schlesinger was replaced by Alois Weis from Medzilaborce, ${ }^{30}$ and Ladislav Hodinka and Liba Veisová were also active in school. ${ }^{31}$ "The orthodox folk school with Slovak as a teaching language had 300 pupils in 1930s, the highest number in its history. Its principal was L'udovít Ganz." ${ }^{32}$ During the period by the end of existence of The First Czechoslovak Republic, the orthodox Jewish folk school was still supported by the finances of the religious community. ${ }^{33}$

Table 3. Orthodox Jewish Folk School in Prešov ${ }^{34}$

\begin{tabular}{|l|c|c|c|}
\hline School year & $\begin{array}{c}\text { Number of } \\
\text { classes }\end{array}$ & $\begin{array}{c}\text { Number of } \\
\text { pupils }\end{array}$ & $\begin{array}{c}\text { Number of } \\
\text { teachers }\end{array}$ \\
\hline $1937 / 1938$ & 5 & 245 & 5 \\
\hline $1938 / 1939$ & 5 & 256 & 5 \\
\hline $1939 / 1940$ & 5 & 271 & 5 \\
\hline $1940 / 1941$ & 6 & 408 & 6 \\
\hline
\end{tabular}

It had five classes with 245 pupils in the school year 1937/1938. At that time, there were five teachers and one teacher of the religious education. The number of classes remained the same also in the following school year, when the school was attended by 256 pupils, 152 of them were boys and 104 girls. The number of pupils increased in the school year 1939/1940 to 271 and the teacher Nella Brillová was replaced by Henrich Roth. In the school year 1940/1941 there was a growth of this school, because it had six classes with one branch and it was attended by 408 pupils and there were six teachers. According to the data from the archive, Frederika Župníková started to teach there ${ }^{35}$ and poor children were still provided with food and clothes. The institution named Cheder was used by the orthodox community for teaching the basics of religion and Hebrew and the religious education was still active in the unofficial school Talmud Torah.

The Jewish neologic folk school was similarly administered and financed by the religious community. At the beginning of The Czechoslovak Republic's existence, this five-class school "with Slovak as a teaching

28. R. J. Buchler, 2010, 164.

29. "Vianočné nádielky v prešovských školách" ["Christmas presents in schools of Prešov"], ŠARIŠ 4, (1930): 4.

30. "Osobné zmeny v učitel'stve okresu prešovského" ["Personal changes in pedagogy of Prešov District"] ŠARIŠ 5, (1930): 4.

31. "Zmeny v školstve" ["Changes in educational system"], $\check{S} A R I \check{S}$ 42(1930): 5.

32. R. J. Buchler, 2010, 164 - 165.

33. B. Klein-Tesnoskalský, Pamätná kniha mesta Prešova. Diel III. (1938 - 1941) [Memory book of Prešov. Part III] (Prešov: Štátna vedecká knižnica, 2011), 75.

34. Ibid., 2011.

35. Ibid., 2011, 21. 
language was attended by circa 130 pupils". ${ }^{36}$ The pupils of the school organized Sunday fairytale afternoons, during which the Jewish and Golem fairytales were performed for the public. The school chair of Israeli religious community in Prešov elected Izabela Kleinová for the eventual teacher of the folk school in Prešov on the $1^{\text {st }}$ of July $1931 .{ }^{37}$ The teacher Izidor Schwartz was really interested in the new trends in pedagogy and in using of new methods in teaching and he was at the birth of the reform section of teachers, which was founded on the $22^{\text {nd }}$ of September 1937 in Prešov. ${ }^{38}$ In the school year 1937/1938, 65 pupils attended two classes. The administrator of the school was still Izidor Schwartz, who was also the president of the organization of the Jewish teachers in Slovakia; the teacher was Alžbeta Sternová and Adolf Reich was teaching the religious education.

These once splendid school buildings, which documented the level of the education and religious tolerance of the citizens, became the place of suffering and tragedy. In the half of March 1942, town offices detained around 50 representatives of the both religious communities and held them in the building of the neologic school as hostages. This building also served as hospital for the Jews who could not be transported. "Jewish doctors in Prešov, Dr. Ilona Mayerová and Dr. Viktor Gärtner worked in general hospital, which was situated in the Jewish neologic folk school." ${ }^{39}$ The month October 1942 was fatal even for the sick and physically suffering people because the transports were merciless to anyone.

Jewish community lived in the pre-war tolerant Prešov a rich social and cultural life, which was enriched by the edifying activity through the engagement of important individuals, or through the activity of its organizations and associations. Also Jewish women community of Prešov, founded in 1855 as Organization of Jewish women, belonged to them. It was led by Anna Rosenbergová, who turned it into "the significant social and cultural establishment of Prešov and the Šariš region." ${ }^{40}$ The members of women community met at tea parties with dance, whose part was also cultural program - singing of arias, dancing performances etc. ${ }^{41}$

In the town there was also an active Jewish minority library with edifying activity, which was directed by library board. At first, it was a part of the local library and on the $6^{\text {th }}$ of July 1930 it was opened as an independent library in the building of Israeli religious community. ${ }^{42}$

36. R. J. Buchler, 2010, 165.

37. State archive in Prešov, The Fund District Authority in Prešov 1923 - 1944, inventory number 220, box number 50, a teacher in Israeli school.

38. I. Schwartz, "Reformná sekcia učitel'ov" ["Reform section of the teachers"], ŠARIŠ, 39 (1937): 4

39. G. Amir, 2004, 180.

40. "Prešovská židovská ženská spoločnost" ["Jewish women society of Prešov"] ŠARIŠ 9(1930): 4.

41. "Čajový večierok židovského ženského spolku v Prešove" ["Tea party of Jewish women organization in Prešov"] $\breve{S} A R I S ̌ ~ 34(1930): 6$.

42. "Knižničná rada mestskej židovskej knižnice" ["Library board of the town's Jewish library"] ŠARIŠ 27(1930): 6. 
The organization of the Jewish academicians in Prešov organized Sunday events "five o' clock" with presentation of music groups, resp. program parties (playing of comedies, small concerts, dancing parties etc.), whose entrance fee was used to support poor students at high schools. ${ }^{43}$

Table 4. Examples of Jewish institutions operating in Prešov from $1871^{44}$

\begin{tabular}{|l|l|}
\hline Agudat Nasim & Women's Association \\
\hline Bejth Jakov & School for girls movement Agudat Israel \\
\hline Bikur Cholim & Association to visit and support the sick people \\
\hline Ez Chajim & $\begin{array}{l}\text { Elementary school for teaching the Talmud and the } \\
\text { Torah }\end{array}$ \\
\hline Gmilat Chesadim & Supporting charitable association \\
\hline Chevra kašida & Burial and social auxiliary fellowship \\
\hline Chevrat Mišniot & Association for Mishnah learning \\
\hline Chevrat šhaš & Circlet for scientific learning of Torah \\
\hline Ješiva & Higher rabbinical school \\
\hline Poale cedek & Religiously-based association of craftsmen \\
\hline Socher Tov & Association for mutual support \\
\hline
\end{tabular}

On the $11^{\text {th }}$ of January 1931, on Sunday at 10:00, the Jewish museum in Prešov was opened with a ceremony and it was installed thanks to Eugen Barkány and Teodor Austerlitz. ${ }^{45}$ "Besides the collecting and studying of sights from the history of the Slovak Jews, it also dealt with the educational and editing activity." ${ }^{46}$ To improve the financial situation of the museum, E. Barkány organized there from the end of May to the beginning of June 1936 a selling exposition of his paintings. "With this exposition of paintings an expert of figures comes in front of the public, which he can show as living life, as ancient past projected from the old times to our present." ${ }^{47}$

"Berith Trumpeldor", the organization of the Jewish scouts in Prešov, spread edifying activity among the youth and it organized Hanukkah parties, just like the one on the $5^{\text {th }}$ of December 1931. It took the name of the onehanded officer of czarist army who excelled in Japan-Russia war and it represented the ideal fighter in Zionist education - a guard. The party went very well; it encouraged the audience financially and morally. Especially precious was the musical performance of the trio A. Staub, Prof. Wollner and Prof. Macht. Finally, the rabbi Dr. Klein said a couple of words about the importance of the Hanukkah day and of the Jewish national movement. ${ }^{48}$

43. "Večierok Spolku židovských akademikov" ["Party of Organization of Jewish academicians"] $\breve{S} A R I \check{S}$ 1(1931): 5.

44. D. Landa, Storočnica. Život a práca židov v Šariši v posledných troch storočiach [Centenary. Life and work of the Jews in Šariš in the last three centuries] (Prešov: Židovská náboženská obec v Prešove, 1997), 60.

45. "Židovské múzeum v Prešove bolo slávnostne otvorené" ["Jewish museum in

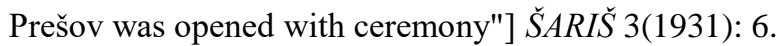

46. P. Konya and P. Landa, 1995, p. 41

47. "Výstava obrazov Prešovčana pána Ing. Eugena Barkánya v Židovskom múzeu v Prešove" ["Exposition of paintings of Prešover mr. Ing. Eugen Barkány in Jewish museum in Prešov"] ŠARIŠ 22(1936): 7.

48. "Prešovský Brith Trumpeldor" ["Brith Trumpeldor of Prešov"] ŠARIŠ 48(1931): 4. 
On the $17^{\text {th }}$ May 1934, the organization organized the Day of Youth ${ }^{49}$ with the lectures and with the constructing of example camp on Cemjata.

Physical and sport club Maccabi in Prešov, which was founded in 1922, contributed to the image of life in the Jewish community. "We only want that the Jewish families, schools and society, everyone with no exception knows our altruistic, educational work with benefit for the Jewish youth and that people in Czechoslovak sphere are sure of our loyalty and honesty in every occasion." ${ }^{50}$ For the citizens it offered exercise in the gym at first in three categories (pupils, women and members from the age of 18), later in four categories - pupils, juveniles, women and men. Football teams of this club were known; also its other branches dealt with sport, for example table tennis, ski, chess, swimming, physical education et cetera. Cultural branch of the club Maccabi offered courses of Hebrew language for the beginning and intermediate learners in the club room, regular Friday lectures for the club members as well as occasional lectures on current topics for the youth and adults. ${ }^{51}$ Beside this, the club also organized for example dance parties with a cultural program. In 1937, also the theatre amateur circle renewed its activity in the club. In this year, on the $22^{\text {nd }}$ March, the club organized its first gymnastic gala in a cinema named Scala. The club had a vision to build its own gym, respectively a culture house, something that could not have happened because of the war events.

\section{The Impact of the Tragic War Events}

After The Munich conference $\left(29^{\text {th }}\right.$ September 1938) and the declaration of the Slovak Republic (14 ${ }^{\text {th }}$ March 1939), anti-Semitic ideas and attitudes started to be spread, whose demonstration was also the destroying of Jewish orthodox synagogue, which happened on the $29^{\text {th }}$ March 1939 and after the bombarding it was consequently sanitized in 1944. It is sad to state that Prešov, once the carrier of the important educational and cultural traditions, became the leader of the anti-Semitic mood and orders at that time, like for example wearing a ribbon on clothes, plundering of property, moving out of main streets, first transports et cetera.

Restriction orders were also applied to the area of education, when in 1939 the Jewish pupils were excluded from all public schools. As a consequence, the neologic and orthodox schools for pupils from the Jewish communities unified. September 1940 brought prohibition of the activity of the Jewish organizations except for religious communities, what in fact meant at the end of any edifying effort. According to the order 208 from the $2^{\text {nd }}$ of September 1940, the Jewish students were excluded from secondary and high schools, what was confirmed by the so-called Jewish codex (September 1941), according to which the Jewish communities could only

49. "Deň mládeže židovskej" ["Day of Jewish youth"] ŠARIŠ 23(1934): 3.

50. "Ideologické prvky v Makabi" ["Ideological features in Makabi"] ŠARIŠ 34(1937): 4.

51. "Kultúrny odbor spolku Makabi v Prešove" ["Cultural department of the Makabi organization in Prešov"] ŠSARIŠ 41(1934): 4. 
administer folk schools and use only their own finances. "Secondary schools were before us closed by the order Numerus clausus, which restricted Jewish participation to $4 \%$, and these were only for the baptized ones." 52 Jewish people attended burgher school in Prešov, which was only used to provide necessary knowledge from the folk school. The Jews and pupils from the extra-town settlements were moved to the newly-created fifth class, where the level of knowledge was the lowest. According to the order of the Jewish codex, the Jewish community had to expand the folk school to six classes and in this sixth class, all the pupils who could not study at the secondary schools before, were placed.

In the war period, only the Jewish library was maintained from the rich educational and edifying activity of the representatives of the Jewish religious community, which was "successfully integrated into the local library, but it was not returned anymore". ${ }^{53}$ Local librarian J. Repčák was the one who saved it, because he sent on the behalf of the local library board on the $6^{\text {th }}$ of May 1942 a letter to Civic authorities in Prešov under the number 57/42, in which he warned, that "the Jewish library contains much precious literature, which could be used for the need of local library, partly for study, academic library". ${ }^{54}$ On the following day, on the $7^{\text {th }}$ of May 1942, he also sent a letter to the government commissar with this request: "Therefore I ask you not to allow to sell the former Jewish library just like other Jewish estates, but to assign it, or better said to return it to town Prešov, from whose finances it was established and completed". ${ }^{55}$ The presidium of the police office in Prešov supported this idea and on the same day it sent the corresponding request to the presidium of Ministry of Finances. The result of this effort to save the funds of the Jewish library was the decision of presidium number 2.198/Pres.S-1943 from the $5^{\text {th }}$ November 1943, which allowed "the Boards of Revenue to sell from a free hand for a properly stated estimated price and other fees the books and other objects of the museum value." ${ }^{56}$ According to the state archive documents, it was finally possible to buy back 42 books in April 1944 and to include them to the fund of the local library.

During the tragic period of the holocaust, around 6,400 Jews of Prešov and its close surrounding died and many objects were damaged or destroyed by the bombing ${ }^{57}$. It is estimated that around 800 Jews from Prešov survived this inhuman period.

52. G. Amir, 2004, 105.

53. D. Landa, 1997, 76

54. State archive in Prešov, The Fund Civic Authorities in Prešov 1923 - 1945, inventory number 144 , box number 27 , ensurance of Jewish library.

55. Ibid.

56. Ibid.

57. P. Konya, 1997, 58. 
Table 5. Number of Citizens of Prě̌ov ${ }^{58}$

\begin{tabular}{|l|c|c|c|}
\hline Year & Number of citizens & Number of Jews & Rate in \% \\
\hline 1787 & 5830 & 1 family & - \\
\hline 1828 & 8187 & 6 families & - \\
\hline 1869 & 10772 & 1010 & $9.4 \%$ \\
\hline 1880 & 10139 & 1229 & $12.1 \%$ \\
\hline 1900 & 13098 & 2106 & $16.1 \%$ \\
\hline 1910 & 16323 & 2637 & $16.2 \%$ \\
\hline 1919 & 18669 & 3492 & $18.7 \%$ \\
\hline 1921 & 17577 & 3477 & $19.8 \%$ \\
\hline 1930 & 21775 & 1702 & $7.82 \%$ \\
\hline 1940 & 24363 & 4308 & $17.7 \%$ \\
\hline 1942 & 24394 & 3855 & $15.8 \%$ \\
\hline 1948 & 20329 & 452 & $2.2 \%$ \\
\hline
\end{tabular}

\section{Conclusion}

Educational and edifying activity of Jewish citizens in Prešov, named for its important school tradition and high level of education by the splendid attribute "Athens upon Torysa", significantly contributed to the understanding of the town on this level. The Jewish religious community, with a gradually growing share of the citizens in the town, presented itself in the town with school buildings, various organizational and edifying activities as well as with people, that are known up to date not only in history of the region. The rise and other hopes were interrupted by the tragic war events and the holocaust, what led to the decimation of the members of the Jewish community in Prešov, together with their culture and educational traditions.

Anti-Semitic feelings appeared also after the liberation of Prešov and they led to the moving of the surviving Jews abroad. The consequential change of the regime in February 1948 also contributed to that and it was evident in the nationalization of the Jewish buildings, respectively in the change of their original purpose. For example the building of the neologic Jewish folk school at street Konštantínova, which belonged to the best equipped school institutions of that time, currently serves the restoration aims; there is a company providing selling and service of calculating and office technology seated in the building of the orthodox folk school at street Okružná.

The most important Jewish representative in Slovakia is Chatam Sofer (own name Moše Schreiber, 1762 - 1839) who belonged to the greatest Jewish scholars of the $19^{\text {th }}$ century. He founded the famous rabbinic training college in Bratislava and a mausoleum, which became a pilgrimage site, was built on the place of his grave.

The famous writer and journalist Yehuda Lahav (1930 - 2010) and Prof. MUDr. Thomas Lehner (*1931), active at the university in London and the

58. R. J. Büchler, 2010, 158. 
holder of the honorary doctorate of the Caroline Institute in Stockholm both lived in Prešov during their childhood. The first Slovak Jewish museum was active during 1928 - 1939 thanks to Eugen Barkány (1885 - 1967) and he also started the research and keeping of many historic artifacts of the Jewish culture, which later became a part of the Jewish community museum in Bratislava. The teacher Izidor Schwartz $(1874-1942)^{59}$ contributed to the area of Jewish literature as a first editor of books about the Jewish history in Slovak language and many others were successful as doctors, scientific workers or merchants. The information about their lives and work from the given period is in the most cases very poor, because it was destroyed by war events, respectively intentionally so we use this form to pay a tribute to their creditable and edifying work.

\section{References}

Amir, G. Prešov - osud židovskej obce, jednej z mnohých [Prešov - the fate of Jewish community, one of the many]. Bratislava: SNM - Múzeum židovskej kultúry, 2004.

Austerlitz, T. and P. Kónya. Kodeš z Orkucan. Súdny proces na základe falošného obvinenia z rituálnej vraždy v r. 1764 [Kodesh from Orkucany. The trial on false charges from ritual murder in 1764]. Prešov: Podnik výpočtovej techniky, 1993.

Buchler, R. J. (Ed.) Encyklopédia židovských náboženských obcí na Slovensku. L-R [Encyclopedia of Jewish religious communities in Slovakia. L-R]. Bratislava: SNM Múzeum židovskej kultúry, 2010.

"Deň mládeže židovskej" ["Day of Jewish youth"]. ŠARIŠ 23(1934): 3.

Ginzburg, C."Microhistory: Two or Three Things That I Know about It." Critical Inquiry 1, (1993): 10-35.

"Ideologické prvky v Makabi" ["Ideological features in Makabi"]. ŠARIŠ 34(1937): 4.

Klein-Tesnoskalský, B. Pamätná kniha mesta Prešova. Diel II. (1701 - 1919) [Memory book of Prešov. Part II]. Prešov: Štátna vedecká knižnica, 2012.

Klein-Tesnoskalský, B. Pamätná kniha mesta Prešova. Diel III (1938 - 1941) [Memory book of Prešov. Part III]. Prešov: Štátna vedecká knižnica, 2011.

"Knižničná rada mestskej židovskej knižnice" ["Library board of the town's Jewish library"]. ŠARIŠ 27(1930): 6.

Konya, P. Dejiny Židov na východnom Slovensku v kontexte celoeurópskeho vývinu [History of the Jews in Eastern Slovakia in the context of the European development]. Prešov: Metodické centrum, 1997.

Konya, P. "Leo Holländer, prvý žid v Prešove" ["Leo Holländer, the first Jew in Prešov"]. In Marek Holländer a vznik židovskej náboženskej obce v Prešove, edited by D. Landa and P.Kónya. Presov: Súkromná tlačiareň Juraj Kušnír, 1999.

Konya, P. and P. Landa. Stručné dejiny prešovských Židov [A brief history of Jews in Prešov]. Prešov: Podnik výpočtovej techniky a. s. Bratislava divízia Prešov pre Židovskú náboženskú obec Prešov, 1995.

59. I. Schwartz, Beruria, židovské rozprávky a povesti [Beruria, jewish fairy tales and legends] (Prešov: Vydavatel'stvo židovskej knižnice, 1932); I. Schwartz, et al. Královná zo Šaby: a iné rozprávky rôznych autorov [Queen of Sheba: and other fairy tales of various authors] (Prešov: Spolok židovských učitel'ov v ČSR, 1937). 
Kónyová, A. "Židia na Prešovskom evanjelickom kolégiu do roku 1918" ["Jews at Evangelic College of Prešov until 1918"] In Židia pred a za Karpatmi v priebehu stáročí, edited by P. Kónya. Prešov: Vydavatel'stvo Prešovskej univerzity v Prešove, 2013.

"Kultúrny odbor spolku Makabi v Prešove" ["Cultural department of the Makabi organization in Prešov"]. ŠARI ̌ 41(1934): 4.

Landa, D. Storočnica. Život a práca židov v Šariši v posledných troch storočiach [Centenary. Life and work of the Jews in Šariš in the last three centuries]. Prešov: Židovská náboženská obec v Prešove, 1997.

Lukáč, E. Stredné školy v Prešove do roku 1945 [Secondary schools in Prešov until 1945]. Prešov: Privatpress, 2002.

Mešt’an, P. "Stručný pohl’ad do histórie"["A brief view into the history"]. In Židia pred a za Karpatmi v priebehu stáročí, edited by P. Kónya. Prešov: Vydavatel'stvo Prešovskej univerzity v Prešove.

"Osobné zmeny v učitel'stve okresu prešovského" ["Personal changes in pedagogy of Prešov District"]. ŠARIŠ 5, (1930): 4.

"Prešovská židovská ženská spoločnost" ["Jewish women society of Prešov"]. ŠARIŠ 9(1930): 4.

"Prešovský Brith Trumpeldor" ["Brith Trumpeldor of Prešov"]. ŠARIŠ 48(1931): 4.

Schwartz, I. Beruria, židovské rozprávky a povesti. [Beruria, jewish fairy tales and legends.] Prešov: Vydavatel'stvo židovskej knižnice, 1932.

Schwartz, I. "Reformná sekcia učitel'ov" ["Reform section of the teachers"]. ŠARI ̌́, 39 (1937): 4.

Schwartz, I. et al. Královná zo Šaby: a iné rozprávky rôznych autorov [Queen of Sheba: and other fairy tales of various authors]. Prešov: Spolok židovských učitel'ov v ČSR, 1937.

State archive in Prešov, The Fund District Authority in Prešov 1923 - 1944, inventory number 224 , box number 60 , Jewish private apprentice continual school, Act of Ministry of Education and National Edification in Prague from 4.3.1925.

State archive in Prešov, The Fund District Authority in Prešov 1923 - 1944, inventory number 224 , box number 60 , Jewish private apprentice continual school, Curriculum of special continual school for apprentices of locksmithery near workshop of Jewish industrial and shop organization of Prešov.

State archive in Prešov, The Fund District Authority in Prešov 1923 - 1945, inventory number 126, box number 9 , prohibition of school Talmud Torah.

State archive in Prešov, The Fund District Authority in Prešov 1923 - 1944, inventory number 224 , box number 60 , Jewish private apprentice continual school, Report from general meeting of JOINT organization.

State archive in Prešov, The Fund District Authority in Prešov 1923 - 1944, inventory number 220, box number 50, a teacher in Israeli school.

State archive in Prešov, The Fund Civic Authorities in Prešov 1923 - 1945, inventory number 144, box number 27, ensurance of Jewish library.

Švorc, P. (Ed.). Sprievodca po historickom Prešove [A guide through the historical Prešov]. Prešov: UNIVERSUM, 2006.

Vasil'ova, D, and L. Franková, Z dejín prešovského kolegiálneho gymnázia (1804 1918). [From the history of Evangelic College Secondary Grammar School of Prešov (1804 - 1918)]. Presov: Filozofická fakulta Prešovskej univerzity, 2012.

"Večierok Spolku židovských akademikov" ["Party of Organization of Jewish academicians"]. ŠARIŠ 1(1931): 5.

"Vianočné nádielky v prešovských školách" ["Christmas presents in schools of Prešov"]. ŠARIŠ 4(1930): 4. 
"Výstava obrazov Prešovčana pána Ing. Eugena Barkánya v Židovskom múzeu v Prešove" ["Exposition of paintings of Prešover mr. Ing. Eugen Barkány in Jewish museum in Prešov"]. ŠARIŠ 22(1936): 7.

"Židovské múzeum v Prešove bolo slávnostne otvorené" ["Jewish museum in Prešov was opened with ceremony"]. ŠARIŠ 3(1931): 6.

"Židovského ženského spolku v Prešove" ["Tea party of Jewish women Čajový večierok organization in Prešov"]. ŠARIŠ 34(1930): 6.

"Zmeny v školstve" ["Changes in educational system"]. ŠARIŠ 42, (1930): 5. 
